\title{
PENERAPAN METODE PEMBELAJARAN AKTIF TIPE CARD SORT UNTUK MENINGKATKAN HASIL BELAJAR SISWA PADA POKOK BAHASAN HUKUM BACAAN NUN SUKUN DAN TANWIN
}

\author{
(Penelitan Tindakan Kelas Terhadap Siswa Kelas VII Semester II SMP Terpadu Al- \\ Fatih Cikalongwetan)
}

\author{
Syifa Salamah \\ Universitas Islam Negeri Sunan Gunung Djati, Bandung, 40614 \\ Email : Salamahsyifa87@gmail.com
}

\begin{abstract}
The purpose of this study is to answer the problems posed on the formulation of the problem, namely (1) student learning outcomes before using the method of active learning type of card sort, (2) the process of applying the method of card sort, (3) and student learning outcomes after using the method of learning active type card sort on the subject of the law of reading nun breadfruit and tanwin. This research is a Classroom Action Research (PTK). The object of research is the process of learning the subject of law reading sukun nun and tanwin in class VII second semester of junior Al Fatih Cikalongwetan. And from this research is VIIA class student consisting of 20 students. This study was conducted in two cycles. Research begins with a pretest, process of application and posstest. The instruments used in this research are test, interview and observation. The result of pretest activity done before the implementation of active learning method of card sort type obtained by mean of student learning result 58,8\%. In the process of applying the active learning method of card sort type can be applied well and obtained the average learning outcomes of students in the 80\% I cycle. Then continued on the second cycle and obtained the average student learning outcome of $94 \%$. This shows that the learning process from cycle I to cycle II has increased by $14 \%$. Thus the application of active learning method type card sort can improve student learning outcomes on the subject of law reading nun breadfruit and tanwin class VII second semester of Al Fatih Junior High Shool in Cikalongwetan.
\end{abstract}

Keyword :

Classroom Action Research, Active Learning, Card Sort

\begin{abstract}
Abstrak : Tujuan dari penelitian ini adalah untuk menjawab permasalahan yang diajukan pada perumusan masalah, yaitu (1) hasil belajar siswa sebelum menggunakan metode pembelajaran aktif tipe card sort, (2) proses penerapan metode card sort, (3) dan hasil belajar siswa setelah menggunakan metode pembelajaran aktif tipe card sort pada pokok bahasan hukum bacaan nun sukun dan tanwin. Penelitian ini merupakan Penelitian Tindakan Kelas (PTK). Objek penelitian adalah proses pembelajaran pokok bahasan hukum bacaan nun sukun dan tanwin pada kelas VII semester II SMP Terpadu Al-Fatih Cikalongwetan. Dan dari penelitian ini adalah siswa kelas VIIA yang terdiri dari 20 siswa. Penelitian ini dilaksanakan dalam dua siklus. Penelitian diawali dengan pretest, proses penerapan dan posstest. Instrumen yang digunakan dalam penelitian ini berupa tes, wawancara dan observasi. Hasil penelitian dari kegiatan pretest yang dilakukan sebelum penerapan metode pembelajaran aktif tipe card sort diperoleh rata-rata hasil belajar siswa $58,8 \%$. Pada proses penerapan metode pembelajaran aktif tipe card sort dapat diterapkan dengan baik dan diperoleh hasil rata-rata belajar siswa pada siklus I 80\%. Kemudian berlanjut pada siklus II dan diperoleh rata-rata hasil belajar siswa sebesar $94 \%$. Hal ini menunjukan bahwa proses pembelajaran dari siklus I sampai siklus II mengalami peningkatan sebesar 14\%. Dengan demikian penerapan metode pembelajaran aktif tipe card sort dapat meningkatkan hasil belajar siswa pada pokok bahasan hukum bacaan nun sukun dan tanwin di kelas VII semester II SMP Terpadu Al-Fatih Cikalongwetan.
\end{abstract}

Kata Kunci :

PTK, Pembelajaran Aktif, Card Sort, Hasil Belajar. 


\section{PENDAHULUAN}

Fakta dilapangan ditemukan bahwa lebih dari 50\% dari 20 siswa nilai peserta didik kelas VII Semester II SMP Terpadu Al-Fatih Cikalongwetan Kabupaten Bandung Barat pada Pokok Bahasan Hukum Bacaan Nun Sukun dan Tanwin masih dibawah Standar Kriteria Ketuntasan Minimal (SKKM) yaitu 75. (Binafsih, Guru PAI SMP Terpadu AlFatih) Hasil Wawancara: Cikalongwetan, 21 Oktober 2017.

Disamping itu dari hasil observasi kelas siswa bersikap pasif ketika berlangsung pembelajaran dikelas. Selama pembelajaran berlangsung siswa menjadi pendengar yang baik. Ketika guru mejelaskan materi pelajaran kebanyakan mereka diam. Demikianpun ketika guru memberikan pertanyaan, sebagian besar siswa diam tanpa komentar. Apalagi ketika guru meminta agar siswa bertanya, merekapun diam. Fakta ini dilatar belakangi karena siswa kurang diberikan strategi/metode pembelajaran yang memadai. Oleh sebab itu dalam proses pembelajaran di sekolah dibutuhkan kreativitas seorang pengajar dalam menerapkan strategi belajar mengajar semenarik mungkin sehingga akan menimbulkan keaktifan dan hasil belajar siswa yang memuaskan khususnya pada pokok bahasan hukum bacaan sukun dan tanwin.

SMP Terpadu Al-Fatih Cikalongwetan merupakan salah satu Sekolah Menengah Pertama (SMP) yang berada di Kabupaten Bandung Barat yang didirikan pada Tahun 2010. Lembaga sekolah ini mempunyai sarana dan prasarana yang masih kurang menunjang dalam proses belajar mengajar hanya dilengkapi perpustakaan dengan koleksi buku-buku pelajaran dan bahan bacaan lainnya yang seadanya, 1 perangkat LCD proyektor yang penggunaannya masih kurang, Kemudian pada proses pembelajaran disekolah ini masih menggunakan metode pembelajaran konvensional sehingga proses pembelajaran disekolah ini masih kurang menarik dan mengakibatkan kejenuhan bagi siswa.

Berkaitan dengan salah satu permasalahan yang dihadapi oleh sekolah yaitu mengenai hasil belajar yang dicapai oleh siswa di SMP Terpadu Al-Fatih yang penyebab utamanya yaitu kurangnya pemahaman siswa dalam memahami konsep dan klasisfikasi yang banyak dari pokok bahasan hukum nun sukun dan tanwin kategori Idzhar, Idghom, Ikhfa, dan Iqlab. Hal ini menyebabkan rendahnya kualitas nilai yang didapat oleh siswa pada mata pelajaran PAI. Nilai yang diperoleh siswa rata-rata hanya sedikit berada diatas KKM yang telah ditetapkan oleh pihak sekolah. Maka dari itu untuk meningkatkan hasil belajar tersebut maka penulis menerapkan metode pembelajaran card sort pada materi tersebut.

Dari berbagai uraian dan latar belakang diatas maka dari itu penulis menganggap bahwa masalah ini penting untuk dicari solusinya maka dari itu penulis melakukan penelitian dan menuangkannya dalam sebuah penelitian tindakan kelas yang bertujuan untuk meningkatkan hasil belajar siswa dengan menerapkan metode pembelajaran aktif tipe card sort. 
Untuk lebih mudah memahami dalam konsep berfikir mengenai penerapan metode pembelajaran aktif tipe card sort ini, perhatikan gambar kerangka berfikir yang telah penulis susun berikut ini :

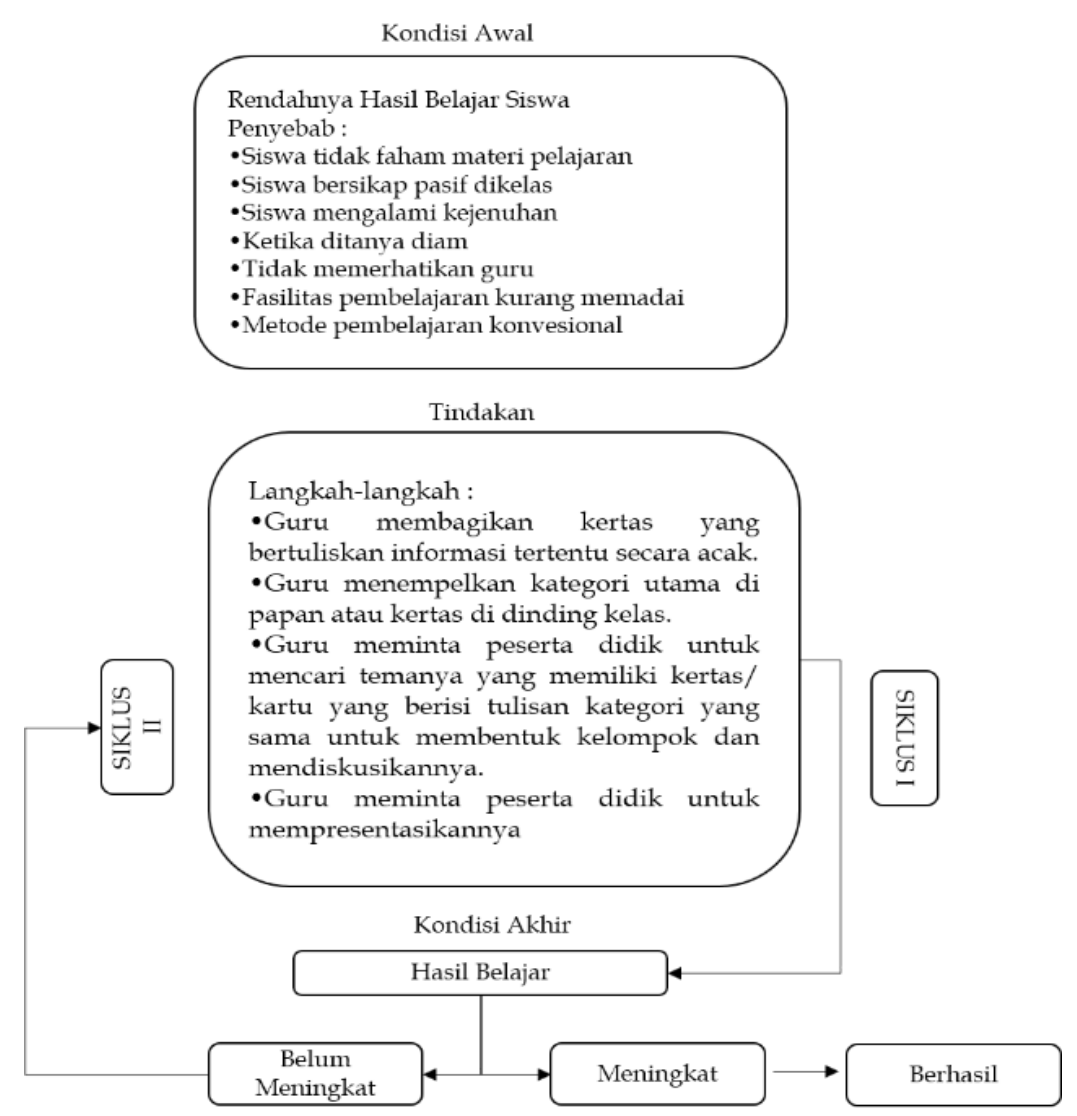

Gambar 1. Kerangka Berfikir

\section{METODOLOGI PENELITIAN}

\section{Metode Penelitian}

Metode Penelitian merupakan cara ilmiah yang digunakan untuk mendapatkan data yang objektif, valid, reliabel, sehingga dapat digunakan untuk memahami, memecahkan dan mengantisipasi masalah dalam bidang tertentu. (Yaya Sunarya dan Tedi Priatna, 2009: 102). Metode yang dipakai oleh peneliti adalah Classroom Action Research atau PTK. Penelitian Tindakan Kelas merupakan suatu pencermatan terhadap kegiatan belajar berupa sebuah tindakan yang sengaja dimunculkan dan terjadi dalam sebuah kelas secara bersama, tindakan tersebut diberikan oleh guru atau dengan arahan dari guru yang dilakukan oleh siswa. (Suharsimi Arikunto, 2006: 6).

Menurut E. Mulyasa (2012:35) Penelitian Tindakan Kelas adalah penelitian tindakan yang dilakukan dengan tujuan untuk memperbaiki kualitas proses dan hasil 
belajar sekelompok peserta didik. Adapun langkah-langkah dalam penelitian ini terdiri dari 2 siklus.

Langkah-langkah penelitiannya mencakup perencanaan, tindakan, observasi dan refleksi. Pada penelitian tindakan kelas ini peneliti menggunakan perangkat pembelajaran yaitu silabus pembelajaran SMP kelas VII semester II, Rencana Perangkat Pembelajaran (RPP), kisi-kisi soal, Instrumen soal, pedoman penskoran, buku siswa dan buku guru dan perangkat pembelajaran yang lainnya. Pada tahap perencanaan peneliti menggunakan silabus pembelajaran dan membuat rencana perangkat pembelajaran serta dilengkapi dengan penggunaan buku guru dan buku siswa untuk menerapkan metode card sort. Selanjutnya pada tahap tindakan peneliti menerapkan skenario yang telah disusun didalam rencana perangkat pembelajaran (RPP) untuk menerapkan tindakan dalam penelitian tindakan kelas ini yaitu menerapkan metode card sort. Pada tahap observasi peneliti bekerja sama dengan guru PAI yang bertindak sebagai observer untuk mengobservasi pelaksanaan penerapan metode card sort mengenai aktivitas siswa sudah sesuai dengan skenario yang telah dibuat pada recana perangkat pembelajaran yang kemudian akan di refleksikan bersama kekurangan-kekurangan yang terjadi untuk diperbaiki pada siklus selanjutnya.

Adapun menurut Yaya Suryana dalam slide konsep dasar dan pola penelitian tindakan kelas (2013: 35) langkah-langkah tersebut dapat dilihat pada gambar berikut ini:

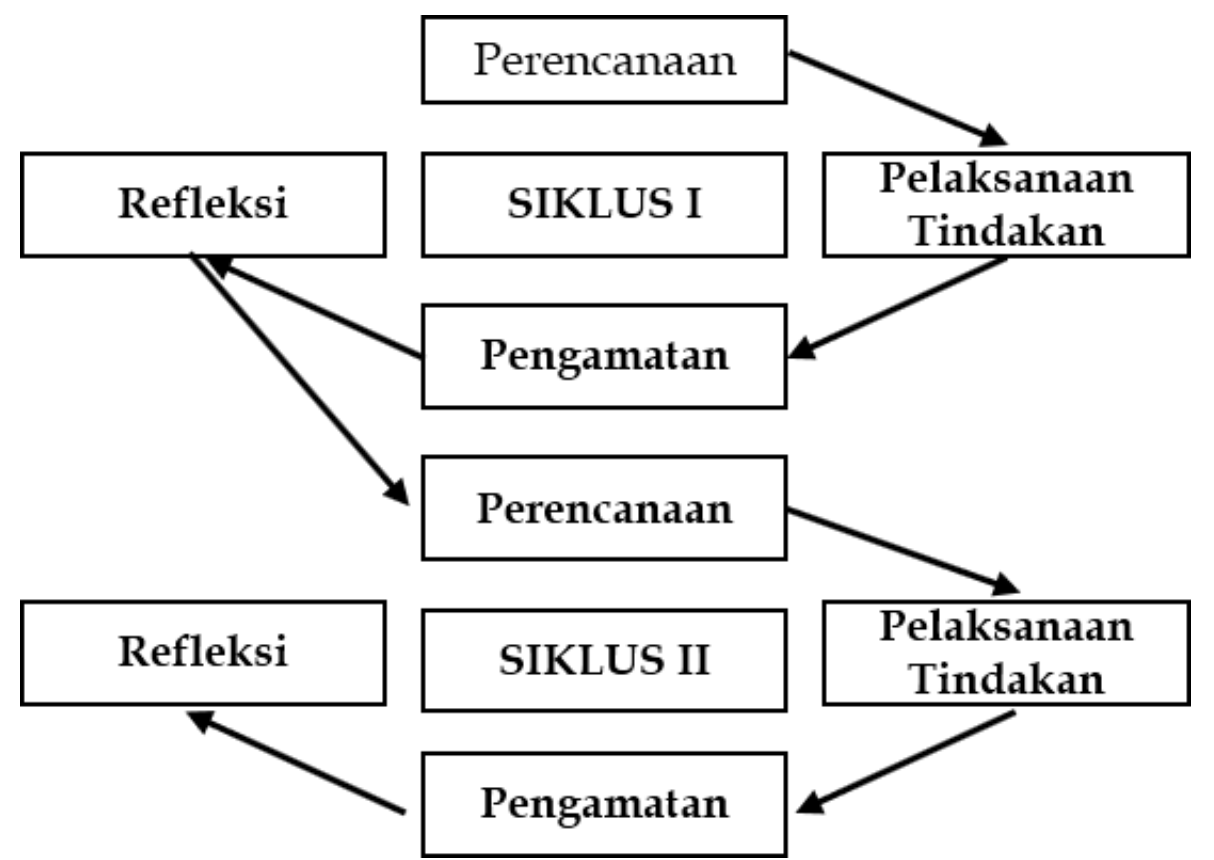

Gambar 2. Langkah-langkah Penelitian Tindakan Kelas

(Hopkins, 1993 dalam Suharsimi, 2006 :105) 


\section{Jenis Data}

Dalam penelitian ini, jenis data yang dikumpulkan untuk memecahkan suatu permasalahan meliputi data kuantitatif dan kualitatif. Data kuantitatif yaitu data yang berasal dari hasil pengumpulan data melalui tes dan observasi. Sedangkan data kualitatif digunakan untuk mendeskripsikan data-data atau informasi yang bersifat menerangkan dalam bentuk uraian.

3. Sumber penelitian

\section{a. Siswa}

Siswa dijadikan sebagai sumber data yang bisa memberikan data berupa jawaban tertulis melaui tes tertulis untuk mengetahui hasil belajar siswa. Adapun untuk populasi dari siswa tersebut yaitu siswa kelas VII semester II SMP Terpadu Al-Fatih Cikalongwetan. Secara kuantitatif jumlah siswa kelas VII berjumlah 42 siswa yang terdiri dari 2 kelas yaitu kelas A dan kelas B. Karena yang gunakan dalam penelitian tindakan kelas ini hanya 1 kelas saja yaitu kelas VII A maka siswa yang diambil sumber data untuk penelitian ini berjumlah 20 siswa.

b. Guru

Guru dijadikan sebagai sumber data yang bisa memberikan data berupa hasil observasi (Daftar Ceklis) untuk menjadi observer dalam pelaksanaan penerapan metode pmbelajaran yang digunakan.

4. Tempat dan Waktu Penelitian

\section{a. Tempat}

Penelitian ini akan dilaksanakan di jenjang Sekolah Menengah Pertama yaitu di SMP Terpadu Al-Fatih yang berlokasi di Yayasan Tandjung Djaja Kp. Rajamandala Rt 03 Rw 12 Desa Mandalamukti Kecamatan Cikalongwetan Kabupaten Bandung Barat.

\section{b. Waktu Penelitian}

Penelitian ini dilaksanakan mulai dari tanggal 27 Februari sampai 20 Maret 2018 dengan susunan jadwal penelitian sebagai berikut :

\begin{tabular}{|c|l|l|l|}
\hline $\begin{array}{c}\text { rtemuan } \\
\text { Ke- }\end{array}$ & Hari & Tanggal & \multicolumn{1}{|c|}{ Kegiatan } \\
\hline I & umat & Maret 2018 & Pree Test \\
\hline II & pelasa & Maret 2018 & $\begin{array}{l}\text { Pertemuan ke-I Siklus 1 Penerapan } \\
\text { metode card sort }\end{array}$ \\
\hline III & umat & Maret 2018 & $\begin{array}{l}\text { Pertemuan ke-II Siklus 1 } \\
\text { Penerapan metode card sort }\end{array}$ \\
\hline IV & pelasa & Maret 2018 & Posttest Siklus I \\
\hline V & umat & Maret 2018 & $\begin{array}{l}\text { Pertemuan ke-I Siklus II } \\
\text { Penerapan metode card sort }\end{array}$ \\
\hline VI & pelasa & Maret 2018 & $\begin{array}{l}\text { Pertemuan ke-I Siklus II } \\
\text { Penerapan metode card sort }\end{array}$ \\
\hline VII & umat & Maret 2018 & Post Test Siklus II \\
\hline
\end{tabular}

Tabel 1. Jadwal Penelitian

5. Teknik Pengumpulan Data Penelitian 
a. Tes Tertulis

Menurut Zainal Arifin (2010: 125) tes tertulis atau sering disebut paper and pancil test adalah tes yang menuntut jawaban dari peserta didik dalam bentuk tertulis. Sedangkan Tes hasil belajar atau Achievement test yaitu tes yang digunakan sebagai alat pengumpul data untuk mengukur pencapaian seseorang setelah mempelajari sesuatu. Berbeda dengan yang lain, tes ini diberikan sesudah orang yang dimaksud mempelajari hal-hal sesuai dengan yang akan diteskan. (Suharsimi Arikunto, 1998: 139-140) Dalam penelitian ini soal-soal yang dibuat untuk pree test (sebelum) dan tes akhir (Post Test) disusun sesuai dengan sub materi pokok yang disampaikan pada tiap siklusnya yang berjumlah 20 soal objektif (Pilihan Ganda). Adapun alat yang digunakan untuk teknik ini yaitu berupa Instrumen soal dilengkapi dengan kisi-kisi soal dan pedoman penskoran.

b. Non Test

\section{1) Observasi}

Observasi merupakan teknik pengamatan dan pencatatan untuk sistematis dari fenomena-fenomena yang diselidiki. (Mahmud, 2011, hal. 168). Observasi digunakan untuk pengumpulan data mengenai aktifitas siswa yang sesuai dengan rpp dalam rangka menjawab rumusan masalah no 2 yaitu bagaimana penerapan metode pembelajaran aktif tipe Card Sort pada pokok bahasan hukum bacaan nun sukun dan tanwin di kelas VII Semester II SMP Terpadu Al-Fatih Cikalongwetan. Adapun alat yang digunakan untuk teknik ini yaitu berupa daftar ceklis (Chek list) yang meliputi aktivitas guru dan aktivitas siswa ketika berlangsungnya proses penerapan metode pembelajaran card sort.

2) Wawancara

Wawancara digunakan untuk pengumpulan data mengenai data lainn yang diperoleh dari sumber data yaitu guru atau pihak lain yang terlibat langsung di lembaga sekolah untuk melengkapai dengan data yang dibutuhkan oleh peneliti. Adapun dalam proses wawancara ini alat yang digunakan untuk wawancara yaitu pedoman wawancara dan instrumen wawancara.

3) Dokumentasi

Dokumentasi digunakan dalam penelitian ini untuk mendokumentasikan atau mengabadikan kejadian-kejadian yang berlangsung dalam penelitian ini. Tujuan dari dokumentasi ini sebagai arsip yang berupa gambar atau foto-foto proses peneitian berlangsung.

6. Teknik Analisis Data Penelitian

1) Analisis hasil pengamatan

Selama pembelajaran berlangsung, dilakukan observasi terhadap aktivitas guru dan siswa. Aktivitas siswa selama pembelajaran diamati dalam waktu selang 10 menit dengan menggunakan lembar khusus. Begitu pula aktivitas guru, dilakukan pengamatan dengan menggunakan daftar ceklis (Chek list) yang telah disediakan.

2) Analisis Tes meningkatkan hasil belajar siswa

Dari hasil tes berupa jawaban-jawaban siswa serta hasil praktek langsung siswa pada setiap akhir siklus (Tes formatif) digunakan untuk mengetahui keberhasilan penelitian tindakan yang telah dilakukan (peningkatan hasil belajar siswa). dan untuk 
mengukurnya digunakan kriteria belajar tuntas, yaitu seorang siswa yang dinyatakan telah tuntas belajar jika penguasaan konsep mencapai $65 \%$ dan sebuah kelas dinyatakan telah tuntas belajar klasikal jika 85\% dari jumlah siswa kelas itu telah mencapai penguasaan konsep 65\% (Depdiknas, Nurjamilah, 2003:5)

Langkah selanjutnya adalah mengubah skor mentah yang diperoleh siswa kedalam bentuk presentasi berdasarkan rumus berikut:

$$
\text { Ketuntasan Belajar Individu : } \frac{\text { Skor yang diperoleh }}{\text { Skor Maksimum }} \times 100 \%
$$

\section{Ketuntasan Belajar Klasikal$$
\text { : } \frac{\text { Banyaknya siswa yang tuntas belajar }}{\text { Banyaknya siswa }} \times 100 \%
$$

Sedangkan untuk keperluan mengklasifikasi kualitas meningkatkan hasil belajar siswa, peneliti menggunakan penilaian sistem skala lima.

\begin{tabular}{|l|l|l|c|c|}
\hline Jo & lya serap & lai & asil Belajar & Kriteria \\
\hline 1 & $90-100$ & A & $90-100$ & Sangat Baik \\
\hline 2 & $75-89$ & B & $75-89$ & Baik \\
\hline 3 & $60-74$ & C & $60-74$ & Cukup \\
\hline 4 & $40-59$ & P & $40-59$ & Kurang \\
\hline 5 & $00-39$ & E & $00-39$ & Sangat Kurang \\
\hline
\end{tabular}

Tabel 2. Teknik Kriteria Penilaian

\section{HASIL KAJIAN DAN PEMBAHASAN}

Kegiatan ini telah dilaksanakan pada hari Jum'at tanggal 9 Maret 2018. Kegiatan Pre Test ini berlangsung selama 2 jam pelajaran ( 2 x 40 menit) yang dimulai pukul 08.30 sampai 09.20 WIB. Adapaun soal-soal yang diberikan adalah mengenai pokok bahasan hukum bacaan nun sukun dan tanwin yang berjumlah 20 soal pilihan ganda (PG). pada kegiatan pre test ini siswa yang hadir berjumlah 20 siswa. Tujuan dari kegiatan pre test ini untuk mengetahui hasil belajar siswa sebelum peneliti melakukan tindakan penerapan metode card sort. Untuk kisi-kisi soal dan instrumen dapat dilihat pada lampiran. Adapun hasil dari kegiatan pre test ini adalah sebagai berikut :

\begin{tabular}{|c|l|c|c|c|c|}
\hline \multirow{2}{*}{ No } & \multirow{2}{*}{ Nama } & \multicolumn{2}{|c|}{ PRETEST } & \multicolumn{2}{c|}{ Tuntas } \\
\cline { 3 - 6 } & & $\begin{array}{c}\text { Jumlah } \\
\text { Skor }\end{array}$ & $\begin{array}{c}\text { Jumlah Skor } \\
\text { Maksimal }\end{array}$ & Ya & Tidak \\
\hline 1. & Ahmad Alfa Rizki & 60 & 100 & & $\sqrt{ }$ \\
\hline 2. & Apis Nasrulloh & 75 & 100 & $\sqrt{ }$ & \\
\hline 3. & Cecep Nurrohman & 50 & 100 & & $\sqrt{ }$ \\
\hline 4. & Desi & 60 & 100 & & $\sqrt{ }$ \\
\hline
\end{tabular}




\begin{tabular}{|c|l|c|c|c|c|}
\hline \multirow{2}{*}{ No } & \multicolumn{1}{|c|}{ Nama } & \multicolumn{2}{|c|}{ PRETEST } & \multicolumn{2}{c|}{ Tuntas } \\
\cline { 3 - 6 } & & $\begin{array}{c}\text { Jumlah } \\
\text { Skor }\end{array}$ & $\begin{array}{c}\text { Jumlah Skor } \\
\text { Maksimal }\end{array}$ & Ya & Tidak \\
\hline 5. & Didin Ardiansyah & 70 & 100 & & $\sqrt{ }$ \\
\hline 6. & Fadilah Maharani & 70 & 100 & & $\sqrt{ }$ \\
\hline 7. & Fitriani & 30 & 100 & & $\sqrt{ }$ \\
\hline 8. & Imas Intan & 70 & 100 & & $\sqrt{ }$ \\
\hline 9. & M. Rizki & 30 & 100 & & $\sqrt{ }$ \\
\hline 10. & Muhamad Ali & 60 & 100 & & $\sqrt{ }$ \\
\hline 11. & Muhamad Mathori & 75 & 100 & $\sqrt{ }$ & \\
\hline 12. & Muhamad Ridwan & 70 & 100 & & $\sqrt{ }$ \\
\hline 13. & Muhammad Yazin & 70 & 100 & & $\sqrt{ }$ \\
\hline 14. & Neng Fuzi Juaheni & 70 & 100 & & $\sqrt{ }$ \\
\hline 15. & Riska Solehah & 70 & 100 & & $\sqrt{ }$ \\
\hline 16. & Sendi Fauzi & 30 & 100 & & $\sqrt{ }$ \\
\hline 17. & Siti Nurhafizah & 60 & 100 & & $\sqrt{ }$ \\
\hline 18. & Trio Maulana & 70 & 100 & & $\sqrt{ }$ \\
\hline 19. & Ujang Suherman & 10 & 100 & & $\sqrt{ }$ \\
\hline 20. & Yusuf Hamdani & 75 & 100 & $\sqrt{ }$ & \\
\hline & $\quad$ Jumlah & $\mathbf{1 1 7 5}$ & $\mathbf{2 0 0 0}$ & $\mathbf{3}$ & $\mathbf{1 7}$ \\
\hline & Rata-Rata & & $\mathbf{1 0 0}$ & & \\
\hline & Ketuntasan Klasikal & & & & $\mathbf{1 5 \%}$ \\
\hline & Skor Tuntas & Skor Ideal & & $\mathbf{1 1 7 5}$ \\
\hline & & & & & \\
\hline
\end{tabular}

Tabel 3. Hasil Pretest

Berdasarkan tabel hasil pretest siswa diatas diperoleh nilai rata-rata siswa 58,8 dengan ketuntasan 15\%. Dari 20 siswa terdapat 3 siswa yang telah mencapai nilai KKM. Ini berarti pada kegiatan pre test ini nilai siswa memang benar-benar belum maksimal dikarenakan belum mengikuti kegiatan proses pembelajaran pokok bahasan hukum bacaan nun sukun dan tanwin. Hasil belajar siswa akan di maksimalkan pada proses pembelajaran siklus 1. Dan apabila pada proses pembelajaran siklus I masih belum maksimal maka akan dilanjutkan kepada tahap selanjutnya yaitu proses pembelajaran siklus II.

\section{Proses Penerapan Metode Card Sort}

Proses pembelajaran berlangsung 2 siklus yang terdiri dari 2 kali pertemuan pada setiap siklusnya dengan menggunakan metode pembelajaran aktif tipe card sort. Penulis menemukan beberapa temuan dari setiap siklus dengan diperoleh data dari 
hasil observasi aktivitas guru dan siswa selama pembelajaran berlangsung sebagai berikut :

a) Pada pertemuan pertama aspek aktivitas mengajar guru dan siswa menunjukan kategori cukup. Semua aspek yang menunjukan pada aktivitas proses pelaksanaan penerapan metode card sort menunjukan kategori cukup. Sedangkan pada pertemuan kedua pengamatan aspek aktivitas mengajar guru dan siswa mengalami peningkatan dengan menunjukan kategori baik.

b) Hasil tes akhir siklus I diperoleh nilai rata-rata siswa sebesar 80. Dari 20 siswa yang mengikuti tes akhir siklus I terdapat 4 siswa yang belum mencapai nilai KKM 75. Hal tersebut menunjukan kegiatan proses pembelajaran masih perlu ditingkatkan lagi pada siklus selanjutnya. Berikut adalah tabel hasil belajar siswa pada siklus I:

\begin{tabular}{|c|c|c|c|c|c|}
\hline \multirow[b]{2}{*}{ No } & \multirow[b]{2}{*}{ Nama } & \multicolumn{2}{|c|}{ SIKLUS I } & \multicolumn{2}{|c|}{ Tuntas } \\
\hline & & $\begin{array}{c}\text { Jumlah } \\
\text { Skor }\end{array}$ & $\begin{array}{c}\text { Jumlah Skor } \\
\text { Maksimal }\end{array}$ & Ya & Tidak \\
\hline 1. & Ahmad Alfa Rizki & 75 & 100 & $\sqrt{ }$ & \\
\hline 2. & Apis Nasrulloh & 90 & 100 & $\sqrt{ }$ & \\
\hline 3. & Cecep Nurrohman & 70 & 100 & & $\sqrt{ }$ \\
\hline 4. & Desi & 80 & 100 & $\sqrt{ }$ & \\
\hline 5. & Didin Ardiansyah & 75 & 100 & $\sqrt{ }$ & \\
\hline 6. & Fadilah Maharani & 85 & 100 & $\sqrt{ }$ & \\
\hline 7. & Fitriani & 75 & 100 & $\sqrt{ }$ & \\
\hline 8. & Imas Intan & 95 & 100 & $\sqrt{ }$ & \\
\hline 9. & M. Rizki & 75 & 100 & $\sqrt{ }$ & \\
\hline 10. & Muhamad Ali & 80 & 100 & $\sqrt{ }$ & \\
\hline 11. & Muhamad Mathori & 90 & 100 & $\sqrt{ }$ & \\
\hline 12. & Muhamad Ridwan & 80 & 100 & $\sqrt{ }$ & \\
\hline 13. & Muhammad Yazin & 80 & 100 & $\sqrt{ }$ & \\
\hline 14. & Neng Fuzi Juaheni & 80 & 100 & $\sqrt{ }$ & \\
\hline 15. & Riska Solehah & 90 & 100 & $\sqrt{ }$ & \\
\hline 16. & Sendi Fauzi & 70 & 100 & & $\sqrt{ }$ \\
\hline 17. & Siti Nurhafizah & 70 & 100 & & $\sqrt{ }$ \\
\hline 18. & Trio Maulana & 80 & 100 & $\sqrt{ }$ & \\
\hline 19. & Ujang Suherman & 70 & 100 & & $\sqrt{ }$ \\
\hline 20. & Yusuf Hamdani & 90 & 100 & $\sqrt{ }$ & \\
\hline \multicolumn{2}{|c|}{ Jumlah } & 1600 & 2000 & 16 & 4 \\
\hline \multicolumn{2}{|c|}{ Rata-Rata } & 80 & 100 & & \\
\hline & & \multicolumn{2}{|c|}{ Ketuntasan Klasikal } & \multicolumn{2}{|c|}{$80 \%$} \\
\hline
\end{tabular}




\begin{tabular}{|c|c|c|c|c|c|}
\hline \multirow[b]{2}{*}{ No } & \multirow[b]{2}{*}{ Nama } & \multicolumn{2}{|c|}{ SIKLUS I } & \multicolumn{2}{|c|}{ Tuntas } \\
\hline & & $\begin{array}{c}\text { Jumlah } \\
\text { Skor }\end{array}$ & $\begin{array}{c}\text { Jumlah Skor } \\
\text { Maksimal }\end{array}$ & Ya & Tidak \\
\hline & & & Skor Tuntas & \multicolumn{2}{|c|}{1600} \\
\hline & & & Skor Ideal & \multicolumn{2}{|c|}{2000} \\
\hline & & & Daya Serap & \multicolumn{2}{|c|}{$80 \%$} \\
\hline
\end{tabular}

Tabel 4. Hasil Belajar Siswa Siklus I

c) Pada siklus II diperoleh hasil observasi aktivitas mengajar guru dan aktivitas kegiatan belajar siswa. Pada pertemuan pertama siklus II aktivitas mengajar guru menunjukan kategori sangat baik. Sedangkan aktivitas kegiatan belajar siswa masih menunjukan kategori baik. Sedangkan pada pertemuan kedua aktivitas mengajar guru dan aktivitas belajar siswa sudah meningkat dengan kategori sangat baik. Hal ini menunjukan peningkatan dan perbaikan dari siklus I dengan melaksanakan rencana-rencana yang telah di rumuskan pada kegiatan refleksi siklus I.

d) Hasil tes akhir siklus II diperoleh nilai rata-rata siswa sebesar 94. Dari 20 siswa yang mengikuti tes akhir siklus II ini seluruh siswa sudah mencapai nilai KKM. Berikut adalah tabel hasil belajar siswa pada siklus II:

3. Kegiatan Posttest

Proses pembelajaran setelah diterapkannya metode pembelajaran aktif tipe card sort pada pokok bahasan hukum bacaan nun sukun dan tanwin ditemukan beberapa 2 hal yang menjadi perubahan. Pertama pada proses pembelajaran yang awalnya membuat siswa pasif dan mengalami kejenuhan setelah diterapkannya metode card sort siswa merasa nyaman dan senang. Metode ini lebih memudahkan siswa dalam memahami materi pelajaran PAI, siswa merasa menyenangkan dan nyaman dalam proses kegiatan pembelajaran dikelas, siswa dapat menemukan konsep-konsep baru dalam pembelajaran PAI, serta lebih aktif dan komunikatif dalam proses pembelajaran berlangsung. Ratarata nilai hasil belajar siswa pada siklus II ini menunjukan predikat A (sangat baik) dengan skor nilai 94 dibandingkan dengan rata-rata nilai hasil belajar siswa pada siklus I yang memperoleh predikat B (baik) dengan skor nilai 80. ini menunjukan peningkatan sebesar 14. Hal tersebut berarti tindakan penelitian berhenti di siklus II, karena tindakan pembelajaran siklus II berhasil meningkatka hasil belajar siswa pada materi PAI pokok bahasan hukum bacaan nun sukun dan tanwin.

\begin{tabular}{|c|c|c|c|}
\hline Penerapan Metode & \multicolumn{3}{|c|}{ Hasil Belajar Siswa } \\
\cline { 2 - 4 } $\begin{array}{c}\text { Pembelajaran Aktif Tipe } \\
\text { Card Sort pada Materi } \\
\text { PAI }\end{array}$ & Pretest & Siklus I & Siklus II \\
\hline Rata-rata Nilai & 58,8 & 80 & 94 \\
\hline
\end{tabular}

Tabel 6.

Rekapitulasi Hasil Belajar Siswa pada Materi PAI 


\section{SIMPULAN}

Berdasarkan hasil penelitian yang telah dilakukan, maka dapat disimpulkan bahwa:

1. Hasil belajar siswa sebelum diterapkannya metode pembelajaran aktif tipe card

\begin{tabular}{|c|c|c|c|c|c|}
\hline \multirow[b]{2}{*}{ No } & \multirow[b]{2}{*}{ Nama } & \multicolumn{2}{|c|}{ SIKLUS II } & \multicolumn{2}{|c|}{ Tuntas } \\
\hline & & $\begin{array}{c}\text { Jumlah } \\
\text { Skor }\end{array}$ & $\begin{array}{c}\text { Jumlah Skor } \\
\text { Maksimal }\end{array}$ & Ya & Tidak \\
\hline 1. & Ahmad Alfa Rizki & 100 & 100 & $\sqrt{ }$ & \\
\hline 2. & Apis Nasrulloh & 100 & 100 & $\sqrt{ }$ & \\
\hline 3. & Cecep Nurrohman & 80 & 100 & $\sqrt{ }$ & \\
\hline 4. & Desi & 100 & 100 & $\sqrt{ }$ & \\
\hline 5. & Didin Ardiansyah & 85 & 100 & $\sqrt{ }$ & \\
\hline 6. & Fadilah Maharani & 100 & 100 & $\sqrt{ }$ & \\
\hline 7. & Fitriani & 80 & 100 & $\sqrt{ }$ & \\
\hline 8. & Imas Intan & 100 & 100 & $\sqrt{ }$ & \\
\hline 9. & M. Rizki & 80 & 100 & $\sqrt{ }$ & \\
\hline 10. & Muhamad Ali & 100 & 100 & $\sqrt{ }$ & \\
\hline 11. & Muhamad Mathori & 100 & 100 & $\sqrt{ }$ & \\
\hline 12. & Muhamad Ridwan & 100 & 100 & $\sqrt{ }$ & \\
\hline 13. & Muhammad Yazin & 100 & 100 & $\sqrt{ }$ & \\
\hline 14. & Neng Fuzi Juaheni & 100 & 100 & $\sqrt{ }$ & \\
\hline 15. & Riska Solehah & 100 & 100 & $\sqrt{ }$ & \\
\hline 16. & Sendi Fauzi & 80 & 100 & $\sqrt{ }$ & \\
\hline 17. & Siti Nurhafizah & 80 & 100 & $\sqrt{ }$ & \\
\hline 18. & Trio Maulana & 100 & 100 & $\sqrt{ }$ & \\
\hline 19. & Ujang Suherman & 80 & 100 & $\sqrt{ }$ & \\
\hline 20. & Yusuf Hamdani & 100 & 100 & $\sqrt{ }$ & \\
\hline \multicolumn{2}{|c|}{ Jumlah } & 1865 & 2000 & 20 & $\mathbf{0}$ \\
\hline \multicolumn{2}{|c|}{ Rata-Rata } & 94 & 100 & & \\
\hline \multicolumn{4}{|c|}{ Ketuntasan Klasikal } & \multicolumn{2}{|l|}{$94 \%$} \\
\hline \multicolumn{4}{|c|}{ Skor Tuntas } & \multicolumn{2}{|l|}{1865} \\
\hline \multicolumn{4}{|c|}{ Skor Ideal } & \multicolumn{2}{|l|}{2000} \\
\hline \multicolumn{4}{|c|}{ Daya Serap } & \multicolumn{2}{|l|}{$94 \%$} \\
\hline
\end{tabular}

sort pada materi PAI pokok bahasan hukum bacaan nun sukun dan tanwin masih dibawah KKM. ini dapat dilihat dari hasil pretest siswa dengan diperoleh ratarata 58,8 dengan ketuntasan belajar $15 \%$. 
2. Penerapan metode pembelajaran aktif tipe card sort pada materi PAI pokok bahasan hukum bacaan nun sukun dan tanwin lebih memudahkan siswa dalam memahami materi pelajaran PAI, siswa merasa menyenangkan dan nyaman dalam proses kegiatan pembelajaran dikelas, siswa dapat menemukan konsepkonsep baru dalam pembelajaran PAI, serta lebih aktif dan komunikatif dalam proses pembelajaran berlangsung.

3. Hasil belajar siswa melalui penerapan metode pembelajaran aktif tipe card sort pada pokok bahasan hukum bacaan nun sukun dan tanwin mengalami peningkatan. Hal ini terlihat pada perolehan hasil belajar setiap siklus, dengan nilai rata-rata pada siklus I sebesar 80 dan rata-ratana nilai siklus II sebesar 94 . Hal tersebut berarti hasil belajar siswa pada materi PAI pokok bahasan hukum bacaan nun sukun dan tanwin mengalami peningkatan sebesar 14 .

\section{DAFTAR PUSTAKA}

Abdul Majid dan Andayani Diana. (2006). Pendidikan Islam Berbasis Kompetensi. Cet III. Bandung : PT. Ramaja Rosdakarya

Abdul Rachman Shaleh. (2000). Pendidikan Agama dan Keagamaan Visi Misi dan Aksi. Cet I. Jakarta : Gemawindu Pancaperkasa.

Abu Ahmad. (1986). Metodik Khusus Pendidikan Agama (MKPA). Bandung: CV Amrico.

AF. Hasanuddin. (1995). Perbedaan Qiraat dan Pengaruhnya Terhadap Istinbath Hukum dalam Al- Quran. Jakarta: PT Raja Grafindo Persada.

Ahmad D Marimba. (1989). Pengantar Filsafat Pendidikan. Bandung : Bumimedia.

Ahmad Fatah Yasin, (2008). Dimensi-Dimensi Pendidikan Islam. Malang: UIN Press.

Ahmad Muthahhar Ibn Abdurrahman al-Maraqi al-Samarani. (2002). Kitab Syifâ'alJinân fî Tarjamah Hidâyah al-Shibyân. Bandung : Al-Malik.

Ahmad Thonthowi. (1993). Psikologi Pendidikan. Bandung : Angkasa al-Ma'arif. Ahmad Zaenal. (2005). Evaluasi Pembelajaran. Bandung: PT. Remaja Rosdakarya. Arief Armai. (2005). Reformulasi Pendidikan Islam. Cet I. Jakarta : CRDS Press. Bimo Walgito. (2004). Bimbingan dan Konseling di Sekolah. Bandung: Tarsito.

Departemen Agama RI. 1993. Petunjuk Pelaksanaan Kurikulum/GBPP Pendidikan Agama Islam di Sekolah Menengah Umum. Jakarta : Direktorat Jendral Pembinaan Kelembagaan Agama Islam.

Dimyati dan Mudjiono. 1996. Belajar dan Pembelajaran. Jakarta: PT. Rineka Cipta. Echlos, Jhon M. dan Shadlly, Hassan .(2007). Kamus Inggris Indonesia. Jakarta : Gramedia.

Evellline Siregar dan Hartini, N. (2010. Teori belajar dan Pembelajaran. Cet I. Bogor : Ghalia Indonesia. 
Gagne, Robert M, dan Leslie J. Briggs, and Walter W Warge. (1992). Principles of Instructional Design. Tx : Hobcourt Brace Ivanovich

Hamzah B Uno. dan Nurdin Mohamad. (2012). Belajar dengan Pendekatan PAILKEM. Jakarta : PT. Bumi Aksara.

Hisyam Zaini, Bermawy Munthe dan Sekar Ayu Aryani. (2006). Strategi

Pembelajaran Aktif di Perguruan Tinggi.Yogyakarta:CTSD.

Hisyam Zaini, Syaiful Bahri. (2010). Strategi Belajar Mengajar. Jakarta : PT. Asdi Mahasatya.

Hisyam Zaini, Syaiful Bahri. (2013). Strategi belajar mengajar mengajar. Jakarta:

PT. Rineka Cipta

Hisyam Zaini. (2008). Strategi Pembelajaran Aktif di Perguruan Tinggi. Yogyakarta: PT. CTSD.

HM, Ahmad Rohani. 2004. Pengelolaan Pengajaran. Jakarta : PT. Asdi Mahasatya.

H.M. Suparta dan Aly, Herry Noer. (2008). Metodologi Pengajaran Agama Islam. Jakarta: Amissco.

Jhonson, Elaine B. (2007). Contextual Teaching Learning : Menjadikan Kegiatan Belajar dan Mengajar Mengasyikan. Bandung : MLC.

Mahmud. (2011). Metode Penelitian Pendidikan. Bandung: CV Pustaka Setia.

Mahmud Yunus. (1983). Metodik khusus Pendidikan Agama. Cet XI. Jakarta : PT. Hidakarya Agung.

Muhaimin. (2005). Pengembangan Kurikulum Pendidikan Agama Islam di Sekolah Madrasah dan Perguruan Tinggi. Jakarta: PT Raja Grafindo Persada.

Muhaimin, Sutiah, dan Nur A. (2004). Paradigma Pendidikan Agama Islam Upaya Mengefektifkan Pendidikan Agama Islam di Sekolah. Bandung: PT Remaja Rosda Karya.

Muhammad Ali. (1996). Guru Dalam Proses Belajar Mengajar. Bandung: Sinar Baru Algesindon.

Mulyasa. (2012). Penelitian Tindakan Kelas. Bandung: PT. Remaja Rosdakarya.

Mulyasa. (2002). Kurikulum Berbasis Kompetensi. Konsep Karakteristik dan Implementasi. Bandung: Rosdakarya.

Muhibbin Syah. (2010). Psikologi Pendidikan. Bandung: PT Remaja Rosda Karya.

M. Amin,. (2011). Panduan Praktis PTK . Yogyakarta: Inspirasi.

M. Idris. . (2008). Strategi \& Metode Pengajaran : Menciptakan Ketrampilan Mengajar yang Efektif dan Edukatif. Jogjakarta: Ar-Ruzz Media Group.

Nana Sudjana. (1995). Dasar-Dasar Proses Belajar Mengajar. Bandung: Sinar Baru Algensindo.

Nana Sudjana. (2002). Penilaian Hasil Belajar Proses Belajar Mengajar. Bandung:

PT.Remaja Rosdakarya.

Nana Sudjana. (2005). Dasar-dasar Proses Belajar Mengajar. Bandung : Remaja Rosdakarya.

Nur Uhbiyati dan Abu Ahmadi. (1997). Ilmu Pendidikan Islam . Bandung: Pustaka. Oemar Hamalik. (2003). Kurikulum dan Pembelajaran. Jakarta : Bumi Aksara. 
Syifa Salamah

Pannen, Paulina. dkk. (2001). Konstruktivisme dalam Pembelajaran. Jakarta : PPAUT Dirjen Dikti Depdiknas.

Robi Sutikno, P. F. (2011). Strategi Belajar Mengajar. Bandung: PT. Refika Aditama.

Roichatul, Jannah \& Siti Nurholifah. (2016). Jurnal Penelitian Tindakan Kelas Pendidikan Agama Islam. Volume 07, Nomor 02, Desember 2016.

Russel, L. (2011). The Accelerated Learning Fieldbook (Panduan Belajar Cepat Untuk Pelajar Dan Umum). Bandung: Nusa Media.

Silberman, M. L. (2012). Active Learning (101) Cara Belajar Siswa Aktif. Bandung: Nuansa.

Slameto. (1991). Belajar dan Faktor-Faktor yang Mempengaruhi. Jakarta:Rineka Cipta. Sugiyono. (2013). Metode Penelitian Pendidikan (Pendekatan Kuantitatif, Kualitatif dan $R \& \quad D)$. Bandung: CV. Alfabeta.

Sulaiman, Al-Jamzuri.. (2011). Kitab Tuhfatul Athfal. Bandung : Al-Malik.

Tim Konsorsium 7 PTAI. (2009). Strategi Pembelajaran. Surabaya: Lapis PGMI.

Trianto.(2010). Mendesain pembelajaran Inovatif Progresif. Cet. III. Jakarta: Kencana Prenada Media Group.

Undang-undang. 2003. Undang Undang Republik Indonesia (UU RI) Th 2003 tentang

Sistem Pendidikan Nasional. http:/www.depdiknas.go.id. diakses pada tanggal 10 Januari 2018.

W.J.S. Poerwadarminta. 1994. Kamus Besar Bahasa Indonesia. Jakarta: Ciputat Pers.

W.S. Winkel. (1994). Psikologi Pendidikan dan Evaluasi Belajar. Jakarta : Gramedia.

Wina, Sanjaya. (2007). Strategi Pembelajran Berorientasi Standar Proses Pendidikan.

Jakarta: Kencana Prenada Media Group.

Yaya Suryana. (2010). Konsep Dasar dan Pola Urp PTK, Ringkasan bahan mata Kuliah untuk program studi PAI.

Zuhairini, dkk. (1983). Metodik Khusus Pendidikan Agama. Surabaya: Usaha Nasional. 